\title{
Yaratıcı Drama Yönteminin Öğretmen Adaylarının Matematik Temel Becerileri’ne İlişkin Görüşleri Üzerindeki Etkisi*
}

\section{The Effect of Creative Drama Method on Teachers' Views on Mathematics Basic Skills}

\author{
Baki ŞAHİ**, Murtaza AYKAÇ***
}

Öz: Bu araştırmanın temel amacı, ilköğretim matematik öğretmen adaylarının yaratıcı drama yönteminin kullanıldığ 1 öğrenme ortamlarında matematik temel becerilerini ne derecede kazandıklarını ve süreçle ilgili görüşlerini belirlemektir. Bu araştırmaya 2. Sınıfta okutulmakta olan seçmeli "Drama Yöntemi ile Matematik Öğretimi" dersini seçen 11 ilköğretim matematik öğretmen adayı katılmıştır. 13 hafta süren uygulamada 20 saat hazırlanan ders planları uygulanmıştır. Uygulama öncesi ve sonrası öğretmen adaylarına matematik temel becerilerini belirlemek amacıyla 7 adet açı uçlu soru sorulmuş, ayrıca her ders palanı uygulaması sonunda öğretmen adaylarının yönteme ilişkin görüşleri alınmıştır. Araştırma verileri uygulama öncesi ve sonrası her soru için temalar oluşturulup, temaların frekans ve yüzdeleri hesaplanarak analiz edilmiştir. Uygulama sonrasında öğretmen adaylarının matematik temel becerilere yönelik olarak yaşantılarından farklı örnekler verebildikleri, yeni kazanımlar elde ettikleri, farkındalık düzeylerinin arttığı gözlenmiştir.

Anahtar Kelimeler: Yaratıcı drama, matematik öğretimi, matematik temel becerileri, öğretmen adayları

\begin{abstract}
The main aim of this research is to determine the degree of mathematics teachers' basic mathematics skills in the learning environments using the creative drama method and their opinions about the process. In this study, 11 primary mathematics pre-service teachers participated who took the elective course "Mathematics Teaching with Drama Method" which was taught in the second year of mathematics education. 20-hour lesson plans, which were prepared for 13 weeks, were applied. 7 open-ended questions were asked before and after the practice to determine the basic skills of pre-service teachers. In addition, after applying each course plan, prospective teachers' opinions about the method were taken, before and after the application of the data, themes were created for each question and the frequencies and percentages of the themes were calculated. After the application, it was observed that pre-service teachers could give different examples from their experiences towards mathematical skills, obtain new gains and increase their awareness.
\end{abstract}

Keywords: Creative drama, mathematics teaching, mathematics basic skills, teacher candidates

\section{Giriş}

Nasıl ki bir yabancı dili öğrenmek için bu dili oluşturan kelimeler ile gramer yapısının bilinmesi gerekli ise matematiği ögrenmek için de onun yapısını oluşturan öğeler olan kavramlar, işlemler ve önermelerinin bilinmesi aralarındaki ilişkiyi oluşturan kuralların bilinmesi gerekir. Eğer bu süreçte eksiklikler olursa yapı tamamlanmamış olur. Bundan sonra öğrenilecek yeni matematik bilgilerinin kazanılması zorlaşabilir. Öğrenme süreci matematiği iyi algılama ile bağlantılıdır. Yaşanılan çevrede görülen nesneler bir şekilde hissedilebilir, duyu organlarıly algılanabilir. Matematik için bu hem mümkün hem de değildir. Tanımını yaptığımız bir matematik kavramını düşünelim. Mesela üçgen. Üçgen, düzlemde birbirlerine paralel olmayan üç doğrunun kesişmesiyle oluşan basit kapalı bir şekildir. $\mathrm{Bu}$ tanım soyuttur. Algılamak için başka

\footnotetext{
* Bu makale, Murtaza Aykaç danışmanlığında özel doğaç yaratıcı drama eğitmenliği/ liderliği programı kapsamında bitirme projesi olarak yazılmıştır.

** Dr. Öğr. Üyesi. Muğla Sıtkı Koçman Üniversitesi, Eğitim Fakültesi, Muğla. ORCID: 0000-0003-0922-648X, eposta: baki@mu.edu.tr

*** Dr. Öğr. Üyesi.Niğde Üniversitesi, Eğitim Fakültesi, Niğde, Türkiye. ORCID: 0000-0001-7204-0835, e-posta: murtazaaykac@gmail.com
} 
kavramları (düzlem, doğru, paralel, basit kapalı eğri) bilmemizi gerektirir. Ama uyarı amacıyla kullanılan bir trafik levhasının üçgen olduğunu söylemek, onu somut yapar. Eğer üçgeni bu şekilde örneklendirerek anlatırsak özellikle somut işlemler dönemindeki çocuklar için algılama çok daha hızlı olur. Bireyin zihninde matematik anlam kazanmaya başlar. Bireylerin matematiği anlayamaması, yapamama korkuları matematik kavramlarının zihinlerinde bir şemasının oluşturamamasından kaynaklanır. Matematiğe dokunamamak, görememek, duyamamak, koklayamamak görünmeyen bir varlığa olan korku gibi ondan çekinmeye, onu yüceltmeye neden olabilir. $\mathrm{Bu}$ korkunun giderilebilmesi ancak matematiğin bireyin hayatında olduğunu hissettirmekle olabilir.

Van De Walle (1989) çocuğun matematik bilgisini geliştirmesi için öğretmeninin ne öğretmesi gerektiği sorusunu kendine sormasının önemini vurguladıktan sonra, matematiğin kavram bilgisi, işlem bilgisi ve kavram ve işlem bilgisi arasındaki ilişkilerin öneminden bahsetmektedir. Kavramlar matematiğin dilidir. Bu dili öğrenmek onu anlamayı sağlar. İşlem bilgisi yalnızca işlem kurallarının uygulanabildiği beceriler değil, işlemlerin kavramsal anlamlarını da bilmeyi içerir. Kavramlar ile işlemler arasındaki ilişkileri kavramak, işlemlere ihtiyaç duyduğumuzda hangisini ne zaman kullanmamız gerektiği tercihini yapmakta kolaylık sağlar. Bir problemde hangi işlemi kullanacağına karar veremeyen bir öğrenci, işlemler ile kavramlar arasında ilişki kuramamış demektir Baykul (2009).

Gerald'a (2002) göre mantık ve akıl yürütme becerisi kavramsal çerçeve ile yakından ilişkilidir. Akıl yürütme becerisi bireylerin kavramsal çerçevelerinin genişliği ve derinliği tarafından belirlenmektedir. NCTM'de (2000) kaliteli bir matematik eğitimi için akıl yürütme, ilişkilendirme ve matematik hakkında okuma ve yazma becerilerinin geliştirilmesine değinmiştir. Matematik derslerinde bu temel kavramlar kazanılamadığında matematik öğrenmede sorunlarla karşılaşılmaktadır. Matematiği anlamlı yapan matematiğin dili olan iletişim becerisi; anlamlı kılan ilişkilendirme becerisi; matematik içi ilişkilendirmelerde niçin? Nasıl? Sorularına cevap ararken, teoremleri ispatlarken kullanılan akıl yürütme becerisi ve gerek hayat problemlerinde gerek matematik problemlerinde sıkça karşılaşılan ve bizi zorlayan problem çözme becerisi matematiğin görünmeyen alt yapısını oluşturmaktadır. 2005 matematik programında (MEB, 2007) ilk kez temel beceriler adı altında yer verilmiş, daha sonra 2013 (MEB, 2013) ve 2018 (MEB, 2018) matematik programında süreç becerileri olarak isimlendirilen bu beceriler, hiçbir öğrenme alanında kazanım olarak yer almamış, ancak etkinlik planlarında yer verilmiştir.

Matematik ögrenmeden kasit kavram ve becerileri bilmekten ziyade matematiğe yatkınlık kazanmaktır (De Corte, 2004). Yani matematik kavramlarına hâkim, sağlam bir işlem bilgisi ve problem çözme becerisindeki yeterlilikler tam olan birey matematiği öğrenmiş demektir. Bu da matematiğe olan ilgiyi arttırır. Matematik öğretiminde temel amaç matematiğe olan ilgiyi arttırmak olmalıdır. Bunun için de matematiği anlamak, matematik yapmaktan zevk almak gerekir. Matematik hayatımızı devam ettirmek için bir ihtiyaçtır. Bunun biliniyor olması bile matematik öğrenmeye olan ilgiyi arttırır. Çocuklar için bu ihtiyaç, çok ileride kullanacağını öğrendiği matematiğe heyecanla, ilgiyle bakmayı sağlamayabilir. Ama bu bilgi alma süreci eğlenceli bir hal alırsa çocuklar için öğrenme istek uyandırabilir. Çünkü çocuk hareketleri gelişmek için yapmaz, hareketten zevk aldığı için yapar ve yaptığı için de gelişir (Skemp, 1986).

Dursun ve Dede (2004) yaptıkları çalışmada 38 matematik öğretmeninin öğrencilerin matematik başarılarını etkileyen etmenler nelerdir sorusuna, on etmen içinden en çok "dersi dinlemeleri" olarak cevap verdiklerini belirtmişlerdir. "Uygulanan öğretim stratejileri ve teknikleri" ise öğretmenlere göre 3. en önemli nedendir. Öğretmenlere göre matematik başarıs1 öğrencinin kendi elindedir. Kersaint (2007) ise öğretmenler, öğrencilerinin farklı bakış açılarıyla problem çözmelerini, matematiksel fikirlerini savunmalarını ve başkalarının fikirlerine de yorum yaparak, matematiksel ilişkileri kullanmaları beklentisi içindeler ise, bunu gerçekleştirmek için uygun öğrenme çevreleri planlamak zorunda olduklarını açıklayarak aynı düşüncede olmadığını belirtmiştir.

Akkuş-İspir (2011), öğrenciler arasında matematik korkusunun yaygın olmasının nedenleri arasında öğretmenin tutumunun, öğretim programının uygulamadaki yetersizliğinin ve 
başarının genel sınavlarla belirlenir olduğunu belirtmiştir. Okullardaki matematik öğretiminin gerçek hayat ile uyumsuz olması öğrencilerin okulda alınan bilgi ve becerileri gerçek hayatta kullanmadan problemleri çözmede yetersiz kalmaları problemler üzerinde düşünmek ve çözüm stratejileri üretmek yerine çabucak sonuca gitmeye çalışmaları bu konudaki araştırmaların yoğunlaşmasına yol açmıştır (Verschaffel, 1999).

Öğretmenin matematikte başarıyı sağlamak için dersi daha zevkli, öğrenilen bilgiler arasında ilişkilerin kurulabildiği, aktif katılımlı yöntemlerin kullanıldığı bir ders haline getirmesi gerekir. San (1991), aşırı ussal, ezbere yönelik, aşırı bilgi yükü, okul yaşamından zevk almaya yönelmeyen, öğrenmenin duyuşsal, sezgisel yanını savsaklayan, öğrencinin yaşayarak öğrenip, kendi sentezlerine varamadığı bir eğitim anlayışının, yetiştirmek durumunda olduğu çağdaş insanın gereksinimlerini karşılayamayacağını vurgulamıştır.

Yaratıcı drama bir öğretim yöntemi olarak matematik derslerinde öğrenciye bu olanakları sağlayabileceği düşünülebilir. Yaratıcı drama yöntemi ile öğrencilere tecrübelerini kullanarak farklı rollerde canlandırmalar yaptıran öğretmenlerin, etkili matematik öğrenme ortamlarının yapılandırılması konusunda farkındalığı arttırılabilir.

Matematik öğretimi daha çok problem çözmeye dayanan bir süreçtir. Bu süreçte öğrencilerin somut ve gerçek hayatla ilişkili problemlerle karşı karşıya getirilmesi önemlidir. Gerçek hayat problemlerini sınıf ortamına taşıyarak öğrencinin problemi daha iyi anlamasına firsat veren öğretim yöntemlerinden yararlanmak gerekir. Yaratıcı drama öğrencinin yaratıcılığını, iletişim gücünü, somut ve soyut düşünme becerilerini ön plana çıkardığı için öğrenciyi aktif olarak öğrenme sürecine katan yaşantılara dayalı zengin bir öğrenme ortamı yaratarak matematik dersinde öğrenci başarısını en üst düzeye çıkarmada etkili olabilecek bir yöntem özelliği taşımaktadır (Aykaç ve Köğce, 2014).

Yaratıcı drama; bir grupla ve grup üyelerinin yaşantılarından yola çıkarak, bir amacın, düşüncenin, doğaçlama, rol oynama (rol alma) vd. tekniklerden yararlanarak canlandırılmasıdır. $\mathrm{Bu}$ canlandırma süreçleri deneyimli bir lider/eğitmen eşliğinde yürütülürken kendiliğindenliğe (spontaniteye), şimdi ve burada ilkesine,- mış gibi yapmaya dayalıdır ve yaratıcı drama, oyunun genel özelliklerinden doğrudan yararlanır (Adıgüzel, 2013).

Yaşantılara dayalı ögretimde kalıcılık \% 90'a ulaşmaktadır (Demirel, 2005). Yaratıcı dramanın da yaşantıların öğrenme ortamında kullanıldığı bir yöntem olarak matematik başarısına önemli katkılar yaptığı yapılan birçok araştırmada ortaya konmuştur. Sedef (2012) yaptığı araştırmada, yaratıcı drama yöntemini içeren etkinliklerin öğrencilerin bilimsel süreç becerileri, bilimsel yaratıcılıklarının ve öz düzenlemelerine olumlu etkileri olduğunu göstermiştir. Sozer (2006) ilköğretim 4. sınıf Matematik dersi "Kesirler" ünitesinde uygulanan drama yönteminin öğrencilerin başarılarına, tutumlarına ve öğrenmenin kalıcıllğına olan etkilerinin incelemek için yaptığı araştırmasında drama yönteminin kullanıldığı deney grubu lehine anlamlı farklar bulmuştur. Soner (2005) de ilköğretim 3. Sınıf matematik dersi kesirli sayılarda toplama ve çıkarma işlemlerinin öğretiminde drama yönteminin geleneksel yönteme göre bilişsel, duyuşsal erişiye ve kalıcılığa anlamlı derecede etki ettiğini bulmuştur. Duatepe (2004), yedinci sınıf öğrencileri ile yaptığı çalışmada drama temelli öğretimin geleneksel öğretim yöntemine göre geometri (açılar ve çokgenler ve daire ve silindir) başarılarına, bu başarıların kalıcılığına, Van Hiele geometrik düşünme düzeylerine, matematiğe ve geometriye karş1 tutumlarına etkisinin anlamlı derecede yüksek olduğunu bulmuştur. Kayhan (2004) da yaratıcı dramanın ilköğretim 3. Sınıf öğrencilerinin uzunluk ölçüleri konusundaki başarıları üzerinde olumlu etkiye sahip olduğunu bulmuştur.

Yaratıcı drama, eğitimcilerin asıl görevlerinden olan çocuk ve ergenlere çeşitli etkileşimleri yaşamaları için olanaklar hazırlamakta, ortamlar sunmakta etkili bir alan ve yöntemdir. Tüm öğrencilerin bedenine, duygularına, düşüncelerine ve çevresinde olup bitenlere karşı bilinçli olmasını amaçlamaktadır. Bir yöntem olarak yaratıcı drama değişik konuları öğretmek gibi öğrenme amaçlı da kullanılabilmektedir. Tüm öğrencilerin ilgilerini genişletmek, gerçekliğe imgeleme aracılığı ile bakabilmeleri ve ulaşabilmelerini, onların öğretilmek istenilenleri anlamalarını sağlamak bu tür çalışmaların amaçları içerisinde yer almaktadır (Adigüzel ve Beştepe, 1999). 
Milli Eğitim Bakanlığının hazırladığı son üç Matematik Öğretim Programı'nın (MEB, 2007; MEB, 20013; MEB, 2018) matematik eğitiminin genel amaçları kısmında yer alan amaçlar incelendiğinde, temel becerilere önemli derecede yer verilmiş olduğu görülebilir. $\mathrm{Bu}$ beceriler, hayatta karşılaşılan zorluklara çözüm üretmeyi amaçlayan problem çözme becerisi, matematiksel bilgilerin matematik içinde diğer bilgilerle, başka derslerle ve disiplinlerle ilişki kurulmasını gerektiren ilişkilendirme becerisi, matematiği doğru anlamayı ve doğru kullanmayı gerektiren iletişim becerisi ve matematik bilgileri arasında mantıksal bir ilişki kurarak anlam çıkarmayı gerektiren akı1 yürütme becerisidir. Temel beceriler yaşam ile matematik arasında ilişki kurmayı, matematiği anlamlı hale getirmeyi amaçlar. Bir yaşam biçimi olarak çocukların sahip olması gereken becerilerdir. Bu becerilere sahip olmak düşünmeyi, sorgulamayı, eleştirmeyi, tartışmayı, birlikte çalışmayı sağlar. Matematik bilgilerini ezberlemeden öğrenmeyi sağlar, yaşam ile ilişkilendirir. Yaratıcı drama yöntemi, bu bilgilerin öğretmen adaylarına kazandırılmasında kullanılabilecek uygun bir yöntem olarak düşünülmüştür. Çünkü temel beceriler yaratıcı drama yönteminin amaçladığı gibi düşünmeyi, çevreye farkındalığı, eleştiriyi gerektirir.

$\mathrm{Bu}$ araştırma kapsamında yaratıcı drama yönteminin öğretmen adaylarının matematik temel becerilerine ilişkin görüşleri üzerindeki etkisinin araştırılması amaçlanmıştır.

\section{Yöntem}

Yaratıcı drama yönteminin öğretmen adaylarının matematik temel becerilerine ilişkin görüşleri üzerindeki etkisinin araştırıldığ çalışmada araştırma betimsel bir durum saptaması niteliğindedir. Araştırmada "Öğretmen adaylarından oluşturulan bir gruba, bir yöntem olarak yaratıcı dramanın kullanıldığı öğretim sürecinde matematik temel becerileri olan İletişim, ilişkilendirme, akıl yürütme ve problem çözme konusuna ilişkin görüşlerini belirlemeyi amaçlayan 20 saatlik yaratıcı drama etkinlikleri uygulanmıştır. Öğretmen adaylarının uygulama öncesinde ve uygulama sonrasında matematik temel becerilerine ilişkin görüşleri betimlenmiş ve karşılaştırmalar yapılmıştır.

\section{Çalışma grubu}

Bu çalışmanın katılımcılarını İlköğretim Matematik Öğretmenliği 2. sınıfta okuyan seçmeli ders olarak "Drama Yöntemi ile Matematik Öğretimi" dersini seçen 11 öğretmen adayı oluşturmaktadır. Katılımcıların seçiminde amaçlı öğretim yöntemlerinden olan benzeşik durum örneklemesi kullanılmıştır. Bu örnekleme yöntemi, evrende araştırmanın problemi ile ilgili olarak benzeşik bir alt grubun, durumun seçilerek çalışmanın burada yapılmasını tanımlar (Büyüköztürk, Çakmak, Akgün, Karadeniz ve Demirel, 2016, s. 91).

\section{Veri toplama süreci ve verilerin analizi}

Çalışma üniversitenin spor salonunda yer alan $60 \mathrm{~m}^{2}$ lik bir salonunda yürütülmüştür. Uygulamalı şekilde devam eden çalışma13 hafta sürmüştür. İlk haftada öğretmen adayları ile tanışma etkinlikleri yapılarak ders ile ilgili bilgilendirme yapılmış ve öğretmen adaylarının drama ile ilgili ön bilgileri sorulmuştur. 2. ve son haftalarda temel beceriler ile ilgili hazırlanan sorular tekrarlı bir şekilde sorulmuştur. 3-13. Haftalarda ise toplam 20 saat süren ders planlarının uygulandığ 10 adet atölye yapılmıştır.

$\mathrm{Bu}$ atölyelerden ilk iki atölyede yaratıcı drama tekniklerini, kurallarını tanımaları ve süreci anlamaları için tanışma, iletişim konuları ele alınmış. Üçüncü ve dördüncü atölyeler problem çözme becerisini, beşinci ve altıncı atölyeler matematikte iletişim becerisini, yedinci ve sekizinci atölyeler akıl yürütme becerisini, dokuzuncu ve onuncu atölyeler ise ilişkilendirme becerisini konu olarak almıştır.

$\mathrm{Bu}$ araştırmada veriler uygulama öncesinde ve sonrasında öğretmen adaylarının 7 açık uçlu soruya verdikleri cevaplar ile oturum sonlarında yapılan değerlendirmeler yoluyla toplanmıştır. Açık uçlu yapılandırılmış sorular, öğretmen adaylarına verdikleri yanıtların nedenlerini de ifade etme imkânı vermekte ve onların bu kavramlarla ilgili düşünme durumlarını yansıtmaktadır (Gronlund ve Linn, 1990). Açık uçlu sorular kazanımlara uygun olacak şekilde 
hazırlanmış, matematik eğitimi alanında görev yapan iki öğretim üyesinin uygunluk açısından görüşüne başvurulmuştur.

Uygulama öncesinde ve sonrasında açı uçlu sorulara öğretmen adaylarının verdikleri cevaplar her soru için içerik analizi yoluyla ayrı ayrı değerlendirilmiştir. Öğretmen adaylarının verdikleri cevaplardan yola çıkarak temalar oluşturulmuş. Oluşturulan temalar bir alan uzmanı tarafından incelenmiş, görüşleri doğrultusunda gerekli düzeltmeler yapılmıştır. Son şekli verilen temalar uygulama öncesi ve sonrası olarak ayrılarak frekans ve yüzde ile ifade edilmiştir. Ayrıca oturum sonlarında öğretmen adaylarının duygu ve düşüncelerini ifade edecekleri değerlendirmeler yaptırılmıştır. Yapılan bu değerlendirmelerde öğretmen adaylarının en çok vurgu yapılan ifadelerine yer verilerek görüşlerinden örnekler sunulmuştur.

\section{Bulgular}

$\mathrm{Bu}$ bölümde öğretmen adaylarının uygulama öncesi ve sonrasında temel becerilerle ilişkin sorulara verdikleri cevaplar ve cevapların içerik analizleri ile oturumlara ilişkin görüşlerine yer verilmiştir. Öğretmen adaylarının uygulama öncesi ve sonrasında her soruya verdikleri cevaplardan temalar belirlenmiş, temalar frekans ve yüzdeler şeklinde ifade edilmiştir. Frekans ve yüzdeler, aynı tablo içinde karşılaştırma yapılacak şekilde sunularak, görüşleri de her temel beceri sonunda verilmiştir.

Illişkilendirme becerisine ilişkin bulgular

Matematik temel becerilerinden "ilişsilendirme" becerisine ilişkin olarak sorulan 1. soru "Matematik içi ilişkilendirme dendiğinde aklınıza ne geliyor?" şeklindedir ve öğretmen adaylarının uygulama öncesi ve uygulama sonrasında vermiş oldukları cevaplara ilişkin frekans ve yüzdeler Tablo 1'de verilmiştir.

Tablo 1.

Öğretmen Adaylarının Uygulama Öncesinde ve Sonrasında "Matematik İçi İlişkilendirme Dendiğinde Aklınıza Ne Geliyor?” Sorusuna Verdikleri Cevaplar

\begin{tabular}{lcccc}
\hline \multirow{2}{*}{ Temalar } & \multicolumn{2}{c}{ Uygulama Öncesi } & \multicolumn{2}{c}{ Uygulama Sonras1 } \\
& \multicolumn{2}{c}{$\mathrm{n}=11$} & & $\mathrm{n}=11$ \\
\cline { 2 - 6 } & $\mathrm{f}$ & $\%$ & $\mathrm{f}$ & $\%$ \\
\hline Konuları arasındaki ilişkilendirme & 6 & 55 & 6 & 55 \\
Bir konuda diğer konudan faydalanmak & 4 & 36 & - & - \\
Matematik işlemler arası ilişkilendirme geliyor & 1 & 9 & - & - \\
Kalıcı öğrenme & - & - & 4 & 36 \\
Diğer dersler, ara disiplinler ile ilişkilendirme & - & - & 1 & 9 \\
Bütün olarak öğrenme & - & - & 2 & 18 \\
Örnek & - & - & 8 & 73 \\
\hline
\end{tabular}

Tablo 1 incelendiğinde, öğretmen adaylarının ifadelerinin çoğunluğunun uygulama öncesinde matematik içi ilişkilendirmenin matematik konuları arasındaki ilişki olduğunu ve konuların birbirlerinden faydalandığı şeklinde olduğu görülmektedir. "Matematik içi ilişkilendirme dendiğinde aklınıza ne geliyor?" sorusuna verilen cevapların, uygulama sonrasında çeşitlendiğini, özellikle de verilen cevapların farklı örneklerle desteklendiği belirlenmiştir. Uygulama sonrasında matematik içi ilişkilendirmenin konular arası ilişkilendirmenin ötesinde kalıcı ve bütüncül öğrenmeyi sağladığının ifade edildiği görülmektedir. Ayrıca öğretmen adaylarının 8 tanesi soruya uygun örnekler vermiş, matematik içi ilişkilendirmenin bir sonucu olan kalıcı öğrenme (4 kişi) ve bütün olarak öğrenme (2 kişi) den bahsetmişlerdir.

Matematik temel becerilerinden "ilişkilendirme" becerisine ilişsin olarak sorulan 2. soru "Matematikle diğer disiplinler ve yaşam arasında ilişkilendirme yapar" cümlesindeki diğer disiplin ve yaşamdan kasıt ne olabilir? Açılayınız" şeklindedir ve öğretmen adaylarının 
uygulama öncesi ve uygulama sonrasında vermiş oldukları cevaplara ilişkin frekans ve yüzdeler Tablo 2 de verilmiştir.

Tablo 2.

Öğretmen Adaylarının Uygulama Öncesinde ve Sonrasında "Matematikle Diğer Disiplinler ve Yaşam Arasında İlişkilendirme Yapar Cümlesindeki Diğer Disiplin ve Yaşamdan Kasıt Ne Olabilir? Açıklayınız” Sorusuna Verdikleri Cevaplar

\begin{tabular}{lcccc}
\hline \multirow{2}{*}{ Temalar } & \multicolumn{2}{c}{ Uygulama Öncesi } & \multicolumn{2}{c}{ Uygulama Sonras1 } \\
& \multicolumn{2}{c}{$\mathrm{n}=11$} & & $\mathrm{n}=11$ \\
\cline { 2 - 6 } & $\mathrm{f}$ & $\%$ & $\mathrm{f}$ & $\%$ \\
\hline Diğer tüm bilimlerle & 2 & 18 & 5 & 46 \\
Diğer dersler & 5 & 46 & 8 & 73 \\
Mimari, mühendislik sanat alanları & 4 & 36 & 5 & 46 \\
Hayatımızdaki matematik & 3 & 27 & 8 & 73 \\
Örnek & - & - & 5 & 46 \\
\hline
\end{tabular}

Tablo 2 incelendiğinde, öğretmen adaylarının diğer bilimler ve mimari, mühendislik, sanat alanları şeklinde ifade ettikleri diğer disiplinlerin uygulama öncesinde az da olsa bazı öğrenciler tarafindan bilindiği görülmektedir. Ancak uygulama sonrasında daha fazla öğrencinin "ilişkilendirme" kavramına hâkim olduğu görülmektedir. Uygulama öncesinde kısa cümleler şeklinde ve tam emin olmadan soruya verilen cevapların, uygulama sonrasında örneklerle desteklenerek, ayrıntılı yorumlar şekilde cevaplandığı görülmektedir. Cevabı diğer disiplinler tüm bilim dalları, matematik dışındaki dersler ve meslek alanları olarak söyleyenlerin sayısında bir artış olduğu tespit edilmiştir.

Öğrenci çalışmalarından örnekler

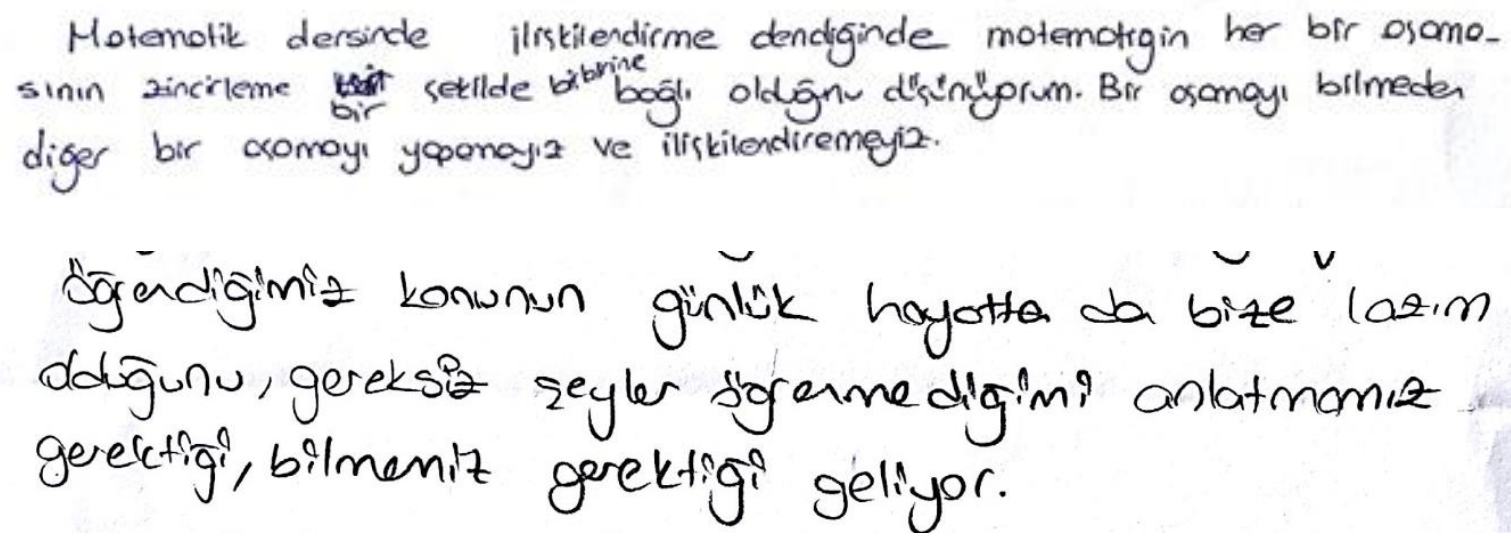

Akıl yürütme becerisine ilişkin bulgular

Matematik temel becerilerinden "akıl yürütme" becerisine ilişkin olarak sorulan 3. soru "Matematik öğrenirken akıl yürütme kullanan bir öğrenci, matematiği nasıl öğrenmektedir?" şeklindedir ve öğretmen adaylarının uygulama öncesi ve uygulama sonrasında vermiş oldukları cevaplara ilişkin frekans ve yüzdeler Tablo 3 'de verilmiştir.

Tablo 3 incelendiğinde, akıl yürütmenin kapsadığı üç özelliğin uygulama öncesinde bazı öğrenciler tarafından ifade edildiği görülmektedir. Bu ifadelerden akıl yürüterek nasıl matematik öğrenilir sorusuna çok küçük bir kısmı ezberlemeden mantıklı ve anlamlı öğrenme cevabını vermiştir. Uygulama sonrasında mantıksal çıkarım yaparak öğrenme, düşünerek, anlamlandırarak, yorumlayarak öğrenme ve ezberin olmaması özelliklerinin ifade sayısının arttığı buna ilave olarak özellikle kalıcıllğın arttığı, küçük adımlarla örtüşük bir öğrenmenin olduğu, eski bilgiler ile iletişimin olduğu ifadelerinin belirtildiği görülmektedir. Bir öğrenci akıl 
yürütme sürecine örnek verirken, bir öğrenci de akıl yürütme sonunda öğrenmenin niteliği ile ilgili kazanımlardan bahsetmiş̧tir. Bunlar da beklenen cevaba yakın cevaplar olarak görülmektedir.

Tablo 3.

Öğretmen Adaylarının Uygulama Öncesinde ve Sonrasında "Matematik Öğrenirken Akıl Yürütme Kullanan Bir Öğrenci, Matematiği Nasıl Öğrenmektedir" Sorusuna Verdikleri Cevaplar

\begin{tabular}{lcccc}
\hline \multirow{2}{*}{\multicolumn{1}{c}{ Temalar }} & \multicolumn{2}{c}{ Uygulama Öncesi } & \multicolumn{2}{c}{ Uygulama Sonras1 } \\
& \multicolumn{2}{c}{$\mathrm{n}=11$} & \multicolumn{2}{c}{$\mathrm{n}=11$} \\
\cline { 2 - 5 } & $\mathrm{f}$ & $\%$ & $\mathrm{f}$ & $\%$ \\
\hline Mantıklı bir şekilde & 5 & 46 & - & - \\
Düşünerek anlamlandırarak yorumlayarak & 5 & 46 & 5 & 46 \\
Ezberlemeden & 2 & 18 & 5 & 46 \\
Mantıksal çıkarımlar yaparak öğrenir. & - & - & 6 & 55 \\
Küçük basamaklardan yararlanarak & - & - & 2 & 18 \\
Kalıc1lı̆̆ arttırır & - & - & 5 & 46 \\
Eski bilgilerini tekrarlar & - & - & 2 & 18 \\
Matematiği daha kolay anlar ilişkiler kurar. & - & - & 1 & 9 \\
Örnek & - & - & 1 & 9 \\
\hline
\end{tabular}

Matematik temel becerilerinden "akıl yürütme" becerisine ilişkin olarak sorulan 4. soru "Yaşantısında ve ya diğer derslerde öğrenirken akıl yürütmeyi kullandığınızı düşünüyor musunuz? Örnekle açıklayınız?” şeklindedir ve öğretmen adaylarının uygulama öncesi ve uygulama sonrasında vermiş oldukları cevaplara ilişkin frekans ve yüzdeler Tablo 4'de verilmiştir.

Tablo 4.

Öğretmen Adaylarının Uygulama Öncesinde ve Sonrasında "Yaşantısında veya Diğer Derslerde Öğrenirken Akıl Yürütmeyi Kullandığınızı Düşünüyor Musunuz? Örneklerle Açıklayınız?" Sorusuna Verdikleri Cevaplar

\begin{tabular}{|c|c|c|c|c|}
\hline \multirow[t]{2}{*}{ Temalar } & \multicolumn{2}{|c|}{$\begin{array}{c}\text { Uygulama } \\
\text { Öncesi } \\
n=11\end{array}$} & \multicolumn{2}{|c|}{$\begin{array}{c}\text { Uygulama } \\
\text { Sonras1 } \\
n=11\end{array}$} \\
\hline & $\mathrm{f}$ & $\%$ & $\mathrm{f}$ & $\%$ \\
\hline Tahmin & 5 & 46 & 3 & 27 \\
\hline Evet düşünüyorum & 10 & 91 & 8 & 73 \\
\hline Düşünmüyorum & 1 & 9 & - & - \\
\hline Problem çözerken kullanıyoruz & 2 & 18 & 2 & 18 \\
\hline $\begin{array}{l}\text { Kendi düşüncelerini açıklarken, matematiksel modelleri, } \\
\text { kuralları ve ilişkileri kullanabilme }\end{array}$ & 1 & 9 & 2 & 18 \\
\hline Ak1l yürütmeyi bazen kullanıyoruz & - & - & 2 & 18 \\
\hline Kullanmiyoruz & - & - & 1 & 9 \\
\hline Mantığa dayalı çıkarımda bulunma & - & - & 4 & 36 \\
\hline Sorgulamadan ezberleyerek öğrenme yok & - & - & 2 & 18 \\
\hline
\end{tabular}

Tablo 4 incelendiğinde birkaç öğrenci hariç genelde uygulama sonrası akıl yürütme temel becerisinin daha fazla özelliğinin içselleştirildiğini, yaşantıya transfer edilmiş olduğunu görmekteyiz. Uygulama öncesi öğretmen adaylarının biri hariç hepsi yaşantılarında akıl yürütmeyi kullandıklarını, akıl yürütmenin tahmin, problem çözme ve matematiksel modelleri kullanma özelliklerinin az da olsa gözlendiğini belirtmişlerdir. Akıl yürütmeyi kullandıklarını gösteren az sayıda ve uygun olmayan örnekler verdikleri görülmüştür. Uygulama sonrasında ise 
akıl yürütme becerisini aslında hayatımızda tam olarak kullanmadığımızı ya da kısmen kullandığımızı düşünen öğrenciler olduğunu görüyoruz. Bunun yanında akıl yürütmenin mantığa dayalı bir çıkarım süreci olduğu, sorgulamadan ezberleyerek öğrenmede akıl yürütülmediği özelliklerinin de özelliklere eklendiğini görmekteyiz. Verilen örneklerin de hepsinin anlamlı olduğu söylenebilir.

Öğrenci çalışmalarından örnekler

Buglln ok,l ylliltme ile ilgili aok farkl hissettim. motemolikte bircpk seyi e्2bere yoptignam farkkettim.

Buguln motemotikte akil yulrultmenin neden bremli oblüunu anlodim. Ginkll birseyleri dürenirken ezber yopmonin eatto montitli olmodijin, disthdïm. Bildigim bilgileri andiz ederek yoptïm islemlere hissettim.

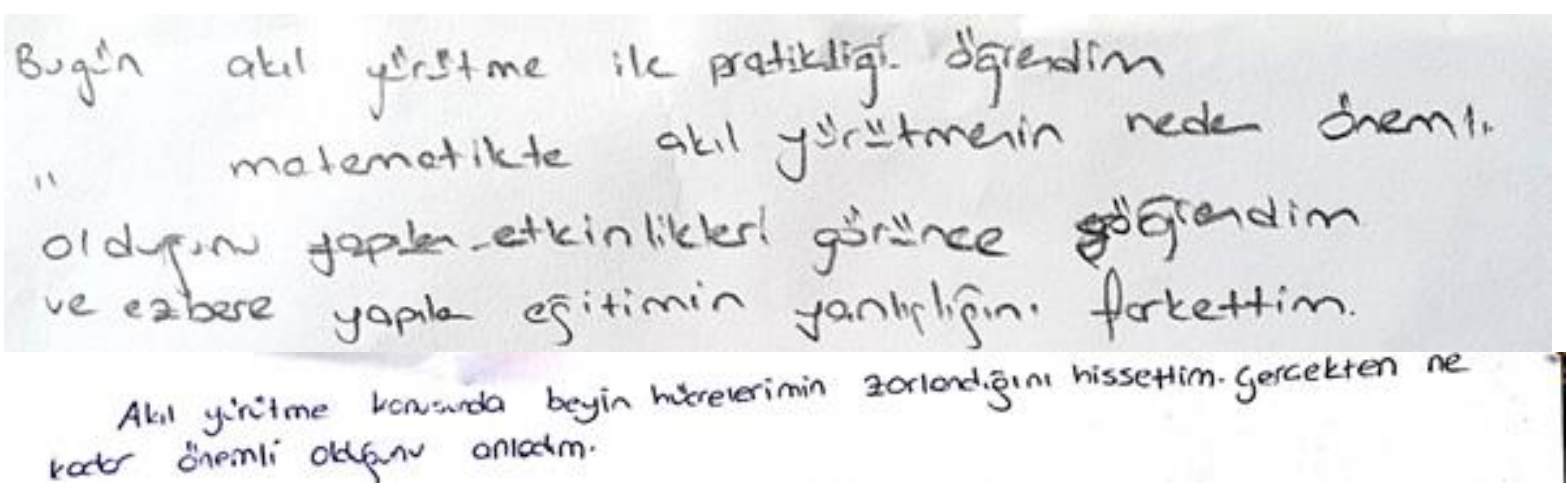

Problem çözme becerisine iliş̧kin bulgular

Matematik temel becerilerinden "problem çözme" becerisine ilişkin olarak sorulan 5. Soru "Gerek matematikte gerekse hayatınızda karşılaştığınız problemleri çözerken hangi aşamaları kullanıyorsunuz?" şeklindedir ve öğretmen adaylarının uygulama öncesi ve uygulama sonrasında vermiş oldukları cevaplara ilişkin frekans ve yüzdeler Tablo 5'de verilmiştir.

Tablo 5

Öğretmen Adaylarının Uygulama Öncesinde ve Sonrasında "Gerek Matematikte Gerekse Hayatınızda Karşılaştığınız Problemleri Çözerken Hangi Aşamaları Kullanıyorsunuz?" Sorusuna Verdikleri Cevaplar

\begin{tabular}{lccccc}
\hline \multirow{2}{*}{\multicolumn{1}{c}{ Temalar }} & \multicolumn{2}{c}{ Uygulama Öncesi } & \multicolumn{2}{c}{ Uygulama Sonras1 } \\
& \multicolumn{2}{c}{$\mathrm{n}=11$} & & \multicolumn{2}{c}{$\mathrm{n}=11$} \\
\cline { 2 - 6 } & $\mathrm{f}$ & & $\%$ & $\mathrm{f}$ & $\%$ \\
\hline Plan yapma & 2 & 18 & - & - \\
Anlama-Plan yapma & 4 & 36 & - & - \\
Anlama-Plan yapma-Planı uygula & 1 & 46 & - & - \\
Anlama-Plan yapma-Çözüm & 1 & 9 & 2 & 18 \\
Anlama-Planı uygulama -Çözüm & 1 & 9 & - & - \\
Plan yapma-Planı uygulama -Çözzum & 1 & 9 & 2 & 18 \\
Anlama-Plan yapma-Planı uygulama -Çözüm & 1 & 9 & 4 & 36 \\
Planı uygulama & - & - & 1 & 9
\end{tabular}


Plan yapma-Uygulama

Planını uygulama -Çözüm

\begin{tabular}{llll}
- & - & 1 & 9 \\
- & - & 1 & 9 \\
\hline
\end{tabular}

Tablo 5 incelendiğinde ön test sonuçlarına göre öğrencilerden problem çözme sürecini tam kullanan olmadığı görülmektedir. Daha çok anlama ve plan yapma aşamasında kalınmıştır. Uygulama sonrasında verilen cevapların ön test sonuçlarına göre iyi olduğu görünse de yeterli bir sonuç değildir. Çünkü sorunun cevabı olan tüm aşamaları gösteren sadece 4 öğrenci olduğu görülmektedir. Bunun nedenleri araştırıldığında o derse dört öğrencinin çeşitli mazeretlerle gelmediği görülmüştür. Bu kadar öğrencinin iştirak etmediği bir atölyenin yine de yapılmış olması bu sonucun etkenlerinden en önemlisi olarak görülmektedir. Doğru cevabın derse katılan öğrencilerin yarısından fazlası tarafından doğru olarak cevaplanmış olması uygulamanın etkisi olarak düşünülebilir.

Matematik temel becerilerinden "problem çözme" becerisine ilişkin olarak sorulan 6 . Soru "Karşılaştığınız bir problemin kaç farklı çözümü ve kaç farklı cevabı olabilir? Neden?" şeklindedir ve öğretmen adaylarının uygulama öncesi ve uygulama sonrasında vermiş oldukları cevaplara ilişkin frekans ve yüzdeler Tablo 6'da verilmiştir.

Tablo 6.

Öğretmen Adaylarının Uygulama Öncesinde Ve Sonrasında "Karşılaştığınız Bir Problemin Kaç Farklı Çözümü ve Kaç Farklı Cevabı Olabilir? Neden?” Sorusuna Verdikleri Cevaplar

\begin{tabular}{lccccc}
\hline \multirow{2}{*}{ Temalar } & \multicolumn{2}{c}{ Uygulama Öncesi } & \multicolumn{2}{c}{ Uygulama Sonrası } \\
& \multicolumn{2}{c}{$\mathrm{n}=11$} & \multicolumn{2}{c}{ n=11 } \\
\cline { 2 - 6 } & $\mathrm{f}$ & $\%$ & $\mathrm{f}$ & $\%$ \\
\hline Birden çok çözüm yolu olabilir & 11 & 100 & 10 & 91 \\
Birden çok cevap & 3 & 27 & 2 & 18 \\
Tek cevap & 1 & 9 & 8 & 73 \\
Bir tane de olabilir birden çok da & 1 & 9 & - & - \\
Hayat problemlerinin birden fazla çözümü vardır & - & - & 1 & 9 \\
Örnek & - & - & 2 & 18 \\
\hline
\end{tabular}

Tablo 6 incelendiğinde öğretmen adaylarının 6. Soruya verdikleri cevapların uygulama öncesi ve sonrasında pek değişmediğini görmekteyiz. Bu durum şu şekilde yorumlanabilir: Uygulamalarda seçilen problemler genelde hayat problemleri şeklinde olmuş, hayat problemlerinin matematik problemlerine transferinin sağlanması düşünülmüştür. Öğrenciler hayat problemleri ile matematik problemlerini genelde ayrı düşünmüşler, bu yüzden bu transferi yapamamışlardır. $\mathrm{Bu}$ yüzden bu kazanımın uygulama ile kazandırılamadığı söylenebilir. $\mathrm{Bu}$ kazanıma, hayat problemleri ile matematik problemlerinin arasındaki ilişkiyi açığa çıkartan etkinliklerin buraya eklenmesi gereksiniminin olduğu görülmektedir. Uygulama sonrasında 8 öğrencinin problemlerin tek cevabı olduğu şeklinde fikir belirttikleri görülmektedir. Bunun nedeni eğitim hayatları boyunca karşılaştıkları problemlerin genelde tek cevaplı problemlerden oluşmuş olması olabilir. Bu çalışmada problemlerin birden fazla cevabının olabileceğine vurgu yapan etkinliklere yer verilmiş olsa da bunun etkili olmadığı düşünülebilir.

Illetişim becerisine ilişkin bulgular

Matematik temel becerilerinden "iletişim" becerisine ilişkin olarak sorulan 7. Soru "Matematikte iletişim kurmak sözünden ne anlıyorsunuz? Açıklayınız?" şeklindedir ve ögretmen adaylarının uygulama öncesi ve uygulama sonrasında vermiş oldukları cevaplara ilişkin frekans ve yüzdeler Tablo 7'de verilmiştir. 
Tablo 7.

Öğretmen Adaylarının Uygulama Öncesinde ve Sonrasında "Matematikte İletişim Kurmak Sözünden Ne Anlıyorsunuz? Açıklayınız?" Sorusuna Verdikleri Cevaplar

\begin{tabular}{lcccc}
\hline \multirow{1}{*}{ Temalar } & \multicolumn{2}{c}{ Uygulama Öncesi } & \multicolumn{2}{c}{ Uygulama Sonras1 } \\
& $\mathrm{n}=11$ & & $\mathrm{n}=11$ & $\%$ \\
\cline { 2 - 6 } & $\mathrm{f}$ & $\%$ & 11 & 100 \\
\hline Matematiğin dili & 4 & 36 & - & - \\
İletişim & 4 & 36 & - & - \\
İlişkilendirme & 1 & 9 & 6 & 55 \\
Evrensel dil & - & - & 3 & 27 \\
Sonuç & - & - & 3 & 27 \\
Örnek & - & - & & \\
\hline
\end{tabular}

Tablo 7 incelendiğinde katılımcıların 7. Soruya verdikleri cevapların uygulama sonrasında belirgin bir şekilde değiştiği görülebilir. Uygulama öncesinde 4 öğrenci matematikte İletişimi matematiğin dili olarak belirtmişler, dört tanesi de kişiler arasında duygu, düşünce, bilgi ve haber alıș verişi anlamında kullanıldığını belirten ifadeler kullanmıșlardır. Bir öğrenci ise ilişkilendirme olarak yorumlamıştır. Uygulama sonrasında son testteki soruya verilen cevaplardan tüm öğretmen adaylarının matematikte iletişimin matematik dili ve onu kullanabilme becerisi olduğunu söylemişlerdir. 6 öğrenci matematik dilini evrensel bir iletişim dili olduğunu belirten ifadeler kullanırlarken, 3 öğrenci iletişime örnekler vermişlerdir. 3 öğrenci ise matematikte yanlış iletişim kurmanın sonuçlarını belirten sözler yazmışlardır. Bu sonuçlar göstermektedir ki uygulama öğrencilere matematikte iletişim kavramını uygulama ve analiz düzeyinde kazandırmıştır.

Öğrenci çallşmalarından örnekler

$$
\text { Sengiti Arkadasin: }
$$

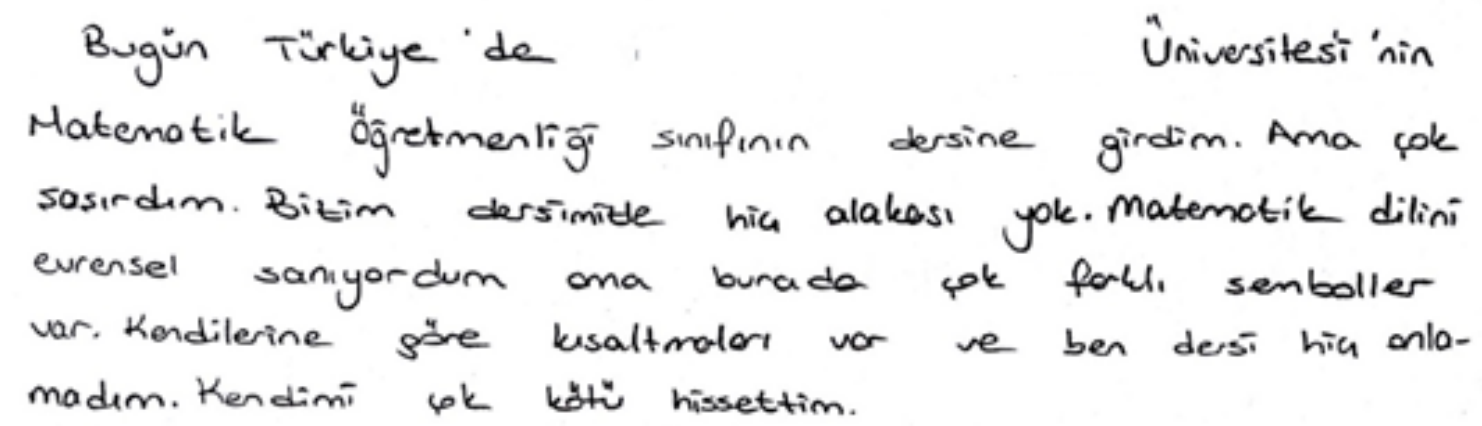




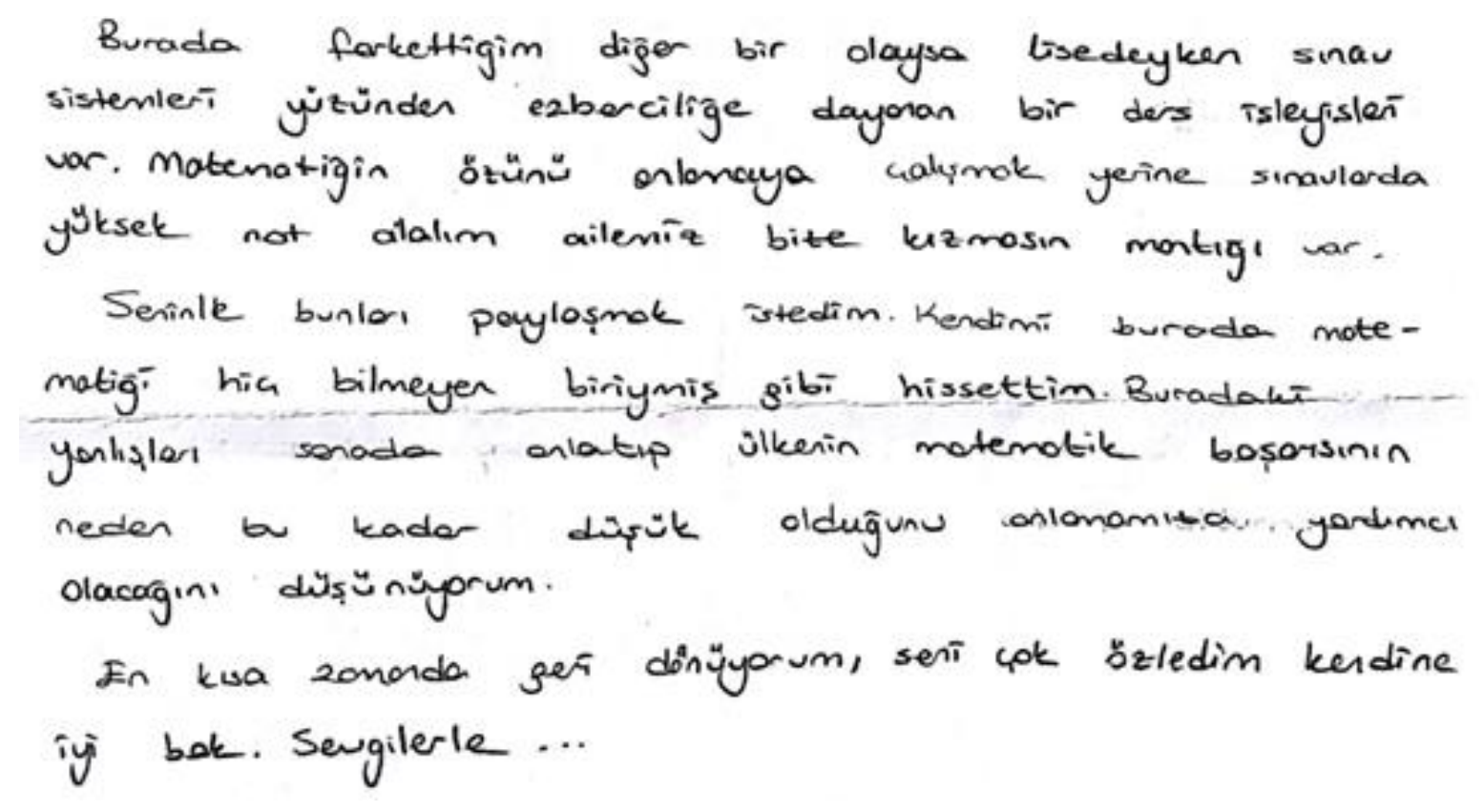

\section{Sonuç ve Tartışma}

Araştırma sonucunda matematik içi ilişkilendirmenin ne olduğu, matematik öğretiminde kullanıldığında öğrencilerin öğrenmeleri üzerinde nasıl sonuçlar doğurabileceği yaratıcı dramanın kullanıldığı öğretim sonucunda öğretmen adaylarının verdikleri cevapları olumlu yönde etkilediği tespit edilmiştir. Yaşantıdan örnek verebilmek için öğrenilen bilginin yaşantı ile ilişkilendirilebilmesi gerekmektedir. Yaratıcı dramanın burada bunu sağladığını söyleyebiliriz. Öğrencilerin oturumlar sonrasında yapılan değerlendirme etkinliklerinde uygulamaya ilişkin görüşlerini belirtirken, sorulara verdikleri cevaplarla tutarlı oldukları görülmektedir. Bu durum kazanımların kalıcı olduğu şeklinde yorumlanabilir.

Uygulama sonrasında öğretmen adaylarının matematik derslerinde ilişkilendirmenin önemi konusunda yeni görüşlere sahip oldukları görülmüştür. Öğrenciler ilişkilendirmenin kalıc1 öğrenmeyi sağladığını, bütün olarak öğrenmeyi kolaylaştırdığını söyleyerek, söylediklerini örneklerle desteklemiş̧lerdir. İlişkilendirmenin boyutlarını fark etmişlerdir. İlişkilendirmenin farklı bir boyutu olan disiplinler ve yaşam ile matematiğin ilişkilendirilmesinin ne olduğu sorulduğunda uygulama sonrasında verilen cevabı destekleyen uygun örneklerin verildiği gözlenmiştir. $\mathrm{Bu}$ sonuçlar doğrultusunda uygulamanın ilişkilendirmenin önemi konusunda öğretmen adaylarının farkındalık düzeylerini arttırdığı söylenebilir.

Matematik öğrenirken akıl yürütme kullanan bir öğrenci, matematiği nas1l öğrenmektedir? Sorusuna verilen cevapların çeşitliliğinin ve tutarlılığının arttığı belirlenmiştir. Uygulama sonrasında akıl yürütmenin özellikle mantıksal çıkarım yaparak öğrenme, düşünerek anlamlandırarak öğrenme, ezberlemeden öğrenme ve kalıcılığı sağlamaya neden olduğu şeklinde görüşlerin yüzdelerinin artmış olması, yöntemin bu kazanımı oluşturmada etkili olduğu şeklinde yorumlanabilir.

Yaşantısında ve ya diğer derslerde öğrenirken akı1 yürütmeyi kullandığınızı düşünüyor musunuz? Örnekle açıklayınız? Sorusuna verilen yanıtlarda öğrenci görüşlerinin evet kullanıyorum diyenlerin sayısında azalma olduğu belirlenmiştir. Yani öğrenciler uygulama sonrasında akıl yürütmenin farklı bir özelliğini söyleyebilmiştir. Öğrenim hayatlarını sorgulayarak akıl yürütmeyi kullanmadan ezbere öğrenmelerin yapıldığı bir ortamda eğitim aldıklarını fark etmişlerdir.

Öğretmen adaylarının problem çözerken ve problem hakkında yorum yaparken kazandıklarının istenilen düzeyde olmadığı söylenebilir. Bunun nedeni olarak da problem çözme sürecinin daha geniş bir zaman istediği, kazanımlarının fazla olması ayrıca da bu 
oturuma katılımın az olması faktörleri düşünülmektedir. Bu sonuçlardan elde edilen bilgiler bizi katılımın az olması durumunda, öğrenmelerin istenen düzeyde sağlanabilmesi için oturumun ertelenmesi gerektiğini düşündürmektedir.

Karşılaştı̆̆ınız bir problemin kaç farklı çözümü ve kaç farklı cevabı olabilir? Neden? Sorusuna verilen cevapların uygulama ile istenen düzeyde artmadığı gözlemlenmiştir. Bir önceki problem çözme oturumuna katılan katılımcıların verdikleri cevaplarında önemli farkl11ıklar gözlemlenirken, katılmayanlarda önemli bir değişim gözlenmemiştir.

Matematik dersinde öğrencilere kazandırılması düşünülen temel becerilerden birisi olan iletişimin uygulama sürecinde öğrenciler tarafından kavrandığı verdikleri cevaplardan anlaşılmaktadır. Ayrıca öğretmen adaylarının matematik derslerinde iletişim becerisinin önemini de kavramış oldukları verdikleri cevaplardan anlaşılabilmektedir. Elde edilen bu bulguları aşağıdaki çalışma sonuçları da destekler niteliktedir. Taş (2008), 29 okulda görev yapan 298 sınıf öğretmenini kapsayan çalışmasında matematik dersinde drama yönteminin kullanılmasının öğrencilerin matematik dersi temel becerilerine katkısını araştırmıştır. Araştırma sonucunda sınıf öğretmenlerinin matematik derslerinde yaratıcı drama yönteminin kullanılmasının öğrencilerin problem çözme, iletişim, ilişkilendirme ve akıl yürütme becerilerinin gelişmesinde olumlu katkısının olacağına inandıklarını ortaya koymuştur.

Çalışmaya genel olarak bakıldığında yaratıcı dramanın sağladığı yaşayarak öğrenme ortamının matematikte temel becerileri kazanma sürecine önemli etkiler yaptığı söylenebilir. Literatürde yapılan çalışmalara bakıldığında ilköğretim 3. sınıf öğrencileri üzerinde, Soner (2005) "kesirlerde toplama ve çıkarma" Kayhan (2004) "uzunluk ölçüleri" konularının ve ilköğretim 4. sınıf öğrencileri üzerinde Sözer (2006) "kesirler" ünitesindeki konuların öğretiminde yaratıcı drama yönteminin kullanılmasının etkilerinin araştırıldığı çalışmalar yapmışlardır. Yaratıcı drama yöntemi öğrenciyi etkin olarak öğrenme sürecine katan, yaşantılara dayalı zengin bir öğrenme ortamı yaratarak öğrenci başarısını en üst düzeye çıkarmada etkili olabilecek bir yöntem özelliği taşıdığı için (Başkaya, 2005; Kayhan ve Argün, 2008; Özer, 2004) yaratıcı dramanın ilkokul düzeyindeki tüm sınıf seviyelerinde uygulanması büyük bir önem taşımaktadır.

Bu çalışma katılımcıların fazla olduğu kontrol gruplu ve nicel veya karma bir çalışma olarak da tasarlanabilir. Ortaokul ve lise düzeyindeki öğrenciler ile belirlenen bir matematik konusunda temel becerilerin yaratıcı drama yöntemi kullanılarak yapılan bir öğretimin etkililiği araştırılabilir. Matematik dersi yapısı gereği soyut bir derstir. Matematik dersinin öğretiminde kullanılan yöntemler çoğu öğrenci için sıkıcı gelmektedir. Matematik konularını neden öğrendiklerini yorumlamakta sıkıntı çekmektedirler. Yaratıcı drama yönteminin matematik derslerinde kullanılması durumunda bu sıkıntıların giderilebileceği düşünülebilir. Bunun için matematik atölyelerinin yaygınlaştırılması ve öğretmenlere ulaştırılması gerekir.

\section{Kaynaklar}

Adıgüzel, H. Ö. ve Beştepe, N. E. (1999). Yaratıcı drama yöntemi ile insan hakları sergisinin kazandırdıkları. 5. Ulusal Sosyal Hizmetler Konferansı, 21-23 Mayıs, Ankara. Hacettepe Üniversitesi, Sosyal Hizmetler Yüksekokulu, Ankara.

Adıgüzel, Ö. (2013). Eğitimde yaratıcı drama. Ankara: Pegem Akademi.

Akkuş-İspir, O. (2011). Korkulan matematik için alternatif bir yöntem: Yaratıcı drama. Ĕ̆itimci Dergisi (1), 5-8.

Aykaç, M. ve Köğce, D. (2014). Sınıf öğretmenlerinin matematik derslerinde yaratıcı drama yöntemini kullanma durumlarının incelenmesi. Journal of History School, 7(XVII), 907-938.

Başkaya, E. (2005). Matematik dersinde yaratıcı drama dersi etkinliklerinden faydalanma (Yayımlanmamış yüksek lisans bitirme projesi). Ankara Üniversitesi, Eğitim Bilimleri Enstitüsü, Ankara.

Baykul, Y. (2009). İlköğretimde matematik ögretimi: 6-8. Sinıflar. Ankara: Pegem Akademi.

Bütüner S. Ö. (2008). 8. Sınıf denklemler konusunun matematik tarihi kullanılarak öğretimi. lkögretim Online, 7(3), 6-1, 2-8. 
Creswell, J. W. (2007). Qualitative inquiry and research design: Choosing among approaches (2nd ed.). Thousand Oaks, CA: Sage

Duatepe, A. (2004). Drama temelli öğretimin yedinci sınıf öğrencilerinin geometri başarısına, Van Hiele geometrik düşünme düzeylerine, matematiğe ve geometriye karşı tutumlarına etkisi (Yayımlanmamış doktora tezi). Orta Doğu Teknik Üniversitesi Fen Bilimleri Enstitüsü, Ankara.

Dursun Ş. ve Dede Y. (2004). Öğrencilerin matematikte başarısını etkileyen faktörler Matematik öğretmenlerinin görüşleri bakımından. Gazi Ĕ̆itim Fakültesi Dergisi, 24(2), 217-23.

Gerald, L. M. Jr. (2002). An evolutionary theory of knowledge and conceptual evolution in science. Global Bioethics, 15(3), 73-8.

Gronlund, N. E. ve Linn, R. L. (1990). Measurement and evaluation in teaching (6th ed.). New York, NY: MacMillan.

Gümüş, F. Ö. ve İspir, O. A. (2014). İlköğretim matematik öğretmen adaylarının gözünden yaratıcı drama ile etkili ögrenme ortamlarının yapılandırılması. Elektronik Sosyal Bilimler Dergisi, 13(51), 241-254.

John, A. Van De Walle. (1989). Elementary school mathematics teaching developmentally. Virginia Commonwealth University.

Kayhan, H. C. (2004). Yaratıcı dramanın ilköğretim 3. Sinıf matematik dersinde öğrenmeye, bilgilerin kalıcılığına ve matematiğe yönelik tutumlarına etkisi (Yayımlanmamış yüksek lisans tezi). Gazi Üniversitesi Eğitim Bilimleri Enstitüsü, Ankara.

Kayhan, H. C. ve Argün, Z. (2008). Yaratıcı drama yöntemine göre hazırlanan öğretim etkinliklerinin öğrencilerin matematik başarılarına etkisi. 17. Ulusal Ĕgitim Bilimleri Kongresi (1-3 Eylül 2008), Sakarya. Sakarya Üniversitesi, Sakarya.

Kersaint, G. (2007). The learning environment: Its influence on what is learned. W. G. Martin ve M. E. Strutchens (Yay. haz.). The learning of mathematics, sixty-ninth yearbook, içinde (s. 259-269). Reston, VA: NCTM.

MEB. (2007). Illköğretim matematik dersi 6-8. sinıflar öğretim programı. Erişim adresi: ttkb.meb.gov.tr/program2.aspx

MEB. (2013). Ortaokul matematik dersi (5, 6, 7 ve 8. sinıflar) ögretim programı. Erişim adresi: ttkb.meb.gov.tr/program2.aspx

MEB. (2018). Matematik dersi öğretim programı. Erişim adresi: ttkb.meb.gov.tr/program2.aspx NCTM. (2000). Principles and Standards for School Mathematics. Reston,

Özer, M. (2004). İlköğretim sosyal bilgiler öğretiminde, yaratıcı drama yönteminin demokratik tutumlara ve ders başarısına etkisi (Yayımlanmamış yüksek lisans tezi). Dokuz Eylül Üniversitesi Eğitim Bilimler Enstitüsü, İzmir.

Sedef A. (2012). Yaratıcı drama etkinliklerinin ilköğretim 7. sını öğrencilerinin bilişsel süreç becerilerine, bilimsel yaratıcllıklarına ve öz düzenlemelerine etkisi (Yayımlanmamış yüksek lisans tezi). Pamukkale Üniversitesi Fen Bilimleri Enstitüsü, Denizli.

Skemp, R. (1986). The psycholog of learning mathematics. Penguin Books, UK.

San, İ. (1991b). Eğitimde drama. TED Illkokul Öğretmenlerine Yönelik Eğitimde Drama Semineri Açılış Konuşması. 2-6 Eylül 1991.

Soner, S. (2005). İlköğretim matematik dersi kesirli sayılarda toplama-çıkarma işlemlerinde drama yöntemiyle yapılan ögretimin etkililiği (Yayımlanmamış yüksek lisans tezi). Abant İzzet Baysal Üniversitesi, Sosyal Bilimler Enstitüsü, Bolu.

Sözer, N. (2006). Illköğretim 4. sinıf matematik dersinde drama yönteminin öğrencilerin başarılarına tutumlarına ve ögrenmenin kalıcıllğına etkisi (Yayımlanmamış yüksek lisans tezi). Gazi Üniversitesi Eğitim Bilimleri Enstitüsü, Ankara.

Taş, F. (2008). İlköğretim 1-5. sinıflar matematik dersi temel becerilerine drama tekniğinin katkısına ilişskin öğretmen görüşleri (Yayımlanmamış yüksek lisans tezi). Abant İzzet Baysal Üniversitesi, Bolu. 
Verschaffel, L., De Corte, E., Lasure, S., Vaerenbergh, B. H. ve Ratinckx, E. (1999). Learning to solve mathematical application problems: A design experiment with fifth graders. Mathematical Thinking and Learning, 1(3), 195-229.

Yıldırım, A. ve Şimşek H. (2006). Sosyal bilimlerde nitel araştırma yöntemleri. Ankara: Seçkin Yayınları.

\section{Extended Abstract}

\section{Introduction}

The aim of mathematics learning is to gain a tendency to mathematics rather than to know the concepts and skills (De Corte, 2004). In other words, the individual who has knowledge of mathematical concepts, a solid knowledge of process and the competence in problem solving skills has learned mathematics. This increases the interest in mathematics. The main objective in mathematics teaching should be to increase the interest in mathematics. For this, it is necessary to understand mathematics and to enjoy mathematics. Mathematics is a need to continue our lives. Even knowing this increases the interest in learning mathematics. This need for children may not provide enthusiasm to the mathematics they learn to use in the future. However, if this process of getting information becomes fun, learning for children can arouse the desire. Because the child does not make the movement to develop, because it takes pleasure in the movement and develops for what it does (Skemp, 1986).

It can be thought that creative drama can provide these opportunities to students in mathematics courses as a teaching method. By using creative drama method, it can be said that teachers who use their experiences in different roles can raise awareness about structuring effective mathematics learning environments.

Creative drama is an effective area and method for preparing environments and providing opportunities for children and adolescents to experience various interactions. It aims to ensure that all students are conscious of their body, emotions, thoughts and what is happening around them. As a method, creative drama can be used for learning purposes, like teaching different subjects. The aim of such studies is to expand the interest of all students, to look at reality through imagery and to enable them to understand and to understand what they want to be taught (Adigüzel \& Beştepe, 1999, p. 1).

Basic skills aim to establish a relationship between life and mathematics and make mathematics meaningful. They are the skills that children should have as a way of life. Having these skills allows thinking, questioning, criticizing, discussing, working together. It provides learning without memorizing mathematics knowledge and associates it with life. The creative drama method has been considered as a suitable method for gaining this knowledge to teacher candidates. Because, basic skills require thinking, environmental awareness, and criticism as intended by the creative drama method. These skills should always be felt during mathematics teaching. Therefore, it requires process-oriented learning

In this study, it has been examined how the mathematics teacher candidates internalize the basic skills of mathematics, communication, association, reasoning and problem solving and their views in this process. The research problem of the study was determined as "What are the views of the mathematics teacher candidates participating in the process of acquiring the basic skills of mathematics on the effect of creative drama?"

\section{Method}

This research has been carried out by qualitative research techniques using the in-class action research type of the Action Research. The participants of this study were 11 pre-service teachers who chose the course "Teaching Mathematics with Drama Method" as an elective course in the Elementary Mathematics Program 2nd year. In the selection of participants, homogeneous sampling method was used from the purposeful sampling methods. 
The ongoing study lasted for 13 weeks. In the first week, students were acquainted with the course and the students' prior knowledge about the drama were asked. In the second and last weeks, questions about basic skills were asked repeatedly. At the 3rd-13th week, the workshops, which lasted for 20 hours, were applied. The data in this study consisted of the responses of the students to 7 open-ended questions before and after the application and the data on evaluation of the sessions collected at the end of the session.

The answers of the students to the open-ended questions before and after the application were evaluated separately for each question. Themes were created based on their answers and these themes were separated before and after the application by frequency and percentage. In addition, evaluations were made at the end of the session to express their feelings and thoughts. In these evaluations, the most emphasized statements of the students and examples were given.

\section{Findings}

According to the obtained qualitative data, it can be said that teacher candidates have reached the findings showing that they internalize basic skills. In the ability of associating teacher trainees, it was observed that they mainly included persistent learning, learning as a whole, and on-site examples which are the reasons of the association skill after the application.

In the case of the acquisition of reasoning skill, students stated that they could make logical inferences, that permanent learning would be provided, and that learning mathematics would be easier. According to them, there is no learning of memorization in reasoning, there is inference based on logic. While evaluating their old learning, they stated that they had done memorization-based learning without reasoning, and stated that they realized that they were able to understand students better in problem-based learning.

Candidates realized that problem solving was a process, not a result, and solved the problems according to the process. They explained the steps of the problem solving process by giving examples. They stated that every written problem is not a problem and there may be more than one answer to the problems.

Prospective teachers stated that communication skills are the language of mathematics and they emphasized the universality of this language, unlike other languages. After specifying what might be the result of using the mathematical language incorrectly, they have included examples of communication.

\section{Conclusion and Discussion}

It can be seen that the mathematical interrelation has a positive effect on the answers of the preservice teachers as a result of the use of creative drama. We observe the most important impact of the participants in different and on-site examples. In order to give an example from the experience, the learned knowledge must be associated with the experience. We can say that the creative drama provided it here. It is observed that students are consistent with the answers they give to the questions in their assessment activities after the sessions. This situation can be interpreted as the achievements are permanent.

In this study, the characteristics of the group, the properties of the subject and the techniques that can be used in the method were reviewed and a preliminary preparation was made. As the study was an only group, the experimental design was determined as one group pretest - posttest. The research method was determined as qualitative research in order to determine the detailed information of the students because of the insufficient number of participants for the quantitative study. One of the negative aspects of the study was the small number of groups. The number of groups with students who did not arrive at the time decreased to 7-8. This made the activities difficult to do. Sessions include warm-up, animation and evaluation activities in accordance with the gains. Animation activities are written to be appropriate for achievements. The 2-hour sessions caused the warm-up and animation times to be kept short. This is considered as a negative factor. In the application process, although students encounter for the first time with creative drama, they have been adapted to the process and their participation has been positive. When we look at the study in general, it can be said 
that by experiencing the creative drama, the learning environment has important effects on the process of gaining basic skills in mathematics.

This study can also be designed as a quantitative or mixed study with a control group in which the participants are high. The effectiveness of a teaching on identified subjects of mathematics by using the creative drama method with secondary or high school students can be investigated. Mathematics is an abstract course due to its structure. The methods used in teaching mathematics are boring for most students. They have difficulty interpreting why they learn mathematics. If the creative drama method is used in mathematics lessons, it can be thought that these problems can be eliminated. For this purpose, mathematics workshops should be disseminated and delivered to teachers. 